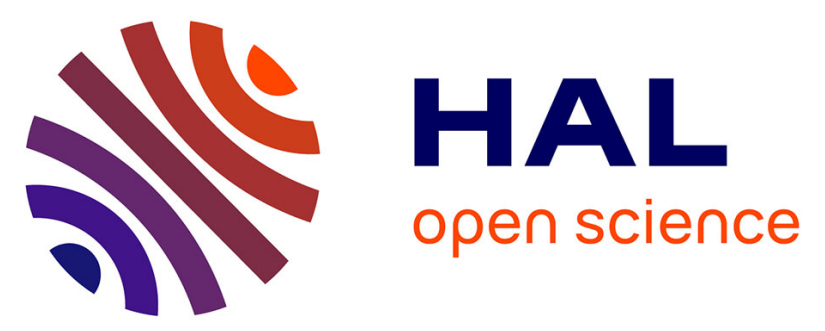

\title{
Making host specificity testing more efficient: Exploring the use of abridged test plant lists
}

Vincent Lesieur, Thierry Thomann, Mélodie Ollivier, Sathyamurthy Raghu

\section{To cite this version:}

Vincent Lesieur, Thierry Thomann, Mélodie Ollivier, Sathyamurthy Raghu. Making host specificity testing more efficient: Exploring the use of abridged test plant lists. Journal of Applied Entomology, 2020, 144 (6), pp.546-551. 10.1111/jen.12760 . hal-02571186

\section{HAL Id: hal-02571186 \\ https://hal.inrae.fr/hal-02571186}

Submitted on 12 May 2020

HAL is a multi-disciplinary open access archive for the deposit and dissemination of scientific research documents, whether they are published or not. The documents may come from teaching and research institutions in France or abroad, or from public or private research centers.
L'archive ouverte pluridisciplinaire HAL, est destinée au dépôt et à la diffusion de documents scientifiques de niveau recherche, publiés ou non, émanant des établissements d'enseignement et de recherche français ou étrangers, des laboratoires publics ou privés.

\section{(ㄷ)(1) $\$$}

Distributed under a Creative Commons Attribution - NonCommerciall 4.0 International 


\title{
Making host specificity testing more efficient: Exploring the use of abridged test plant lists
}

\author{
Vincent Lesieur ${ }^{1,2}$ \\ Thierry Thomann ${ }^{2}$ \\ Mélodie Ollivier $^{1}$ | Sathyamurthy Raghu ${ }^{3}$
}

${ }^{1}$ UMR CBGP, INRA, CIRAD, IRD, Montpellier SupAgro, University of Montpellier,

Montferrier sur Lez, France

${ }^{2}$ CSIRO European Laboratory, CSIRO Health \& Biosecurity, Montferrier sur Lez, France

${ }^{3}$ Ecosciences Precinct, CSIRO Health \& Biosecurity, Brisbane, QLD, Australia

\section{Correspondence}

Vincent Lesieur, UMR CBGP, Montpellier SupAgro, 755 avenue du Campus Agropolis, Montferrier sur Lez 34980, France.

Email: vincent.lesieur@supagro.fr

\section{Funding information}

Australian Government Department of Agriculture; AgriFutures Australia (Rural Industries Research and Development Corporation), Grant/Award Number: PRJ-010527

\begin{abstract}
Testing the specificity of candidate agents is a key component of risk analysis in weed biological control. This step is often time-consuming due to the numerous plant species that need to be tested under quarantine conditions in the invaded country of the weed species. Here, we examined whether an abridged phylogenetically based test list could be used in the weed's native range to quickly screen the host specificity of candidate agents. Ten plant species were used to test the host specificity of a promising candidate for the biological control of Sonchus oleraceus in Australia, the gall midge, Cystiphora sonchi. No-choice and choice tests were carried out in the native Mediterranean range of the midge. The results showed the midge has potential to threaten native Australian species, as those species showed high infestation levels in no-choice tests and produced significantly higher numbers of galls in choice tests. As a result of this approach, $C$. sonchi was rapidly discarded from the list of agents to be imported into Australian quarantines for further tests. This study demonstrates that testing a few key phylogenetically related species in the native range may save cost and effort in a weed biological control programme.
\end{abstract}

KEYWORDS

biological control, cecidomyiidae, common Sowthistle, leaf gall midge, risk assessment, weed

\section{1 | INTRODUCTION}

Native range surveys and risk assessments for host specificity of candidate agents are two vital components of classical biological control programmes (CBC) (Barratt, Moran, Bigler, \& Lenteren, 2017). Typically, prospective agents are successively imported into quarantine facilities in the country where the agents are likely to be released, for the requisite host specificity testing. This phase of biological control research is often the most time-consuming and expensive. Developing methodologies to quickly characterize the host specificity of candidate agents is thus a major challenge (Heard \& Klinken, 2004). In this study, we explored the utility of using focused and abridged test lists to prescreen candidate agents in the native range prior to their importation into quarantine in optimizing this step in $\mathrm{CBC}$ programmes. Specifically, we investigated this in the context of biological control of common sowthistle, Sonchus oleraceus L. (Asteraceae), in Australia.
Sonchus oleraceus is an annual species native to Eurasia and Northern Africa (Boulos, 1973) and has been introduced to several countries around the world (Peerzada, O'Donnell, \& Adkins, 2019). In Australia, the species is now widespread (McCarren \& Scott, 2013) and recognized as among the most difficult weeds to control in grain growing regions of northern Australia (Manalil, Werth, Jackson, Chauhan, \& Preston, 2017;Osten et al., 2007). Development of herbicide resistance in this species is particularly problematic for managing populations in cropping systems, especially in systems with conservation tillage (Peerzada et al., 2019). Although less problematic than S. oleraceus, Sonchus asper (L.) Hill is also an invasive and widely distributed weed in Australia (Scott \& McCarren, 2012). 
biological control agents. Based on a phylogenetic approach, a test list of 41 plant species has been proposed for assessing the specificity of candidate agents for S. oleraceus (Hunter \& Morin, 2018). Instead of successively sending each prospective agent to Australia for testing its specificity in relation to these 41 species in a quarantine facility, we examined whether an abridged phylogenetically based test list could be used to rapidly screen for host specificity in the native range. Specifically, we investigated this in a leaf gall-inducing insect, Cystiphora sonchi Vallot (Diptera: Cecidomyiidae), that is typically thought of as being a specialist agent reported only on $S$. oleraceus, S. asper and other Sonchus species (Peschken, 1982; Rizzo $\&$ Massa, 1998). The midge was previously released in Canada in the 80 s for the biological control of Sonchus arvensis L. (Peschken, McClay, Derby, \& DeClerck, 1989).

\section{2 | MATERIAL AND METHODS}

\section{1 | Test plant list}

Test plants were selected according to the centrifugal phylogenetic approach (Briese, 2005;Wapshere, 1974) and based on the test plant list developed by Hunter and Morin (2018), which includes 41 test species (see Supplementary material for more details). The abridged test plant list we used within our tests (Table 1 ) included two native Australian species, Sonchus hydrophilus Boulos and Actites megalocarpus (Hook.f.) Lander, those species being the only two native
Sonchinae present in Australia (Kim, Lu, \& Lepschi, 2004). Three economically important species and five weed species of European origin, commonly found within the Australian cropping systems and belonging to three sub-tribes closely related to the Sonchinae, were also added. Therefore, the abridged test plant list was composed of ten species from four different sub-tribes within the Lactuceae tribe (Asteraceae family).

\subsection{Insect material}

The biology of the midge is well documented. Up to six generations per year have been observed in Europe (Rizzo \& Massa, 1998). Under laboratory conditions, adults emerge $c a$. 20 days after oviposition (Peschken, 1982). Adults emerge early in the morning and mate soon after emergence. Males live only for a few hours while females may live up to $48 \mathrm{~h}$ (Peschken, 1982). Once mated, females become active in early afternoon, starting oviposition. Females lay their eggs into leaves (DeClerck \& Steeves, 1988). One week after oviposition, the larval trophic activity induces a gall on the upper leaf surface. Mature galls are about $5 \mathrm{~mm}$ in diameter and are red or light green. Then, the larvae pupate within the gall or in the soil.

Cystiphora sonchi used in this study were obtained from a colony maintained at the CSIRO European Laboratory (Montferrier sur Lez, France). The rearing of $C$. sonchi was initiated with naturally infested leaves of S. oleraceus, collected at Montferrier sur Lez, in July 2017. The rearing was maintained on rosettes of S. oleraceus

TAB LE 1 Results of no-choice host range tests for Cystiphorasonchi

\begin{tabular}{|c|c|c|c|c|c|}
\hline Sub-tribe/Species & $\begin{array}{l}\text { Importance in } \\
\text { Australia }\end{array}$ & $\begin{array}{l}\text { Infested plants/ } \\
\text { Tested plants }\end{array}$ & $\begin{array}{l}\text { Proportion of infested } \\
\text { leaves mean }( \pm S E)^{a}\end{array}$ & $\begin{array}{l}\text { Galls per plant } \\
\text { mean }( \pm S E)\end{array}$ & $\begin{array}{l}\text { Adults emerged } \\
\text { mean } \%( \pm S E)\end{array}$ \\
\hline \multicolumn{6}{|l|}{ Sonchinae } \\
\hline $\begin{array}{l}\text { Sonchus oleraceus French } \\
\text { origin }\end{array}$ & Invasive/Weed & $6 / 6$ & $0.75(0.13) \mathrm{a}$ & $105.00(36.63) \mathrm{a}$ & 87.90 (3.19) a \\
\hline $\begin{array}{l}\text { Sonchus oleraceus } \\
\text { Australian origin }\end{array}$ & Invasive/Weed & $6 / 6$ & $0.93(0.05) \mathrm{a}$ & $168.67(50.73) \mathrm{a}$ & 90.10 (1.93) a \\
\hline Sonchus asper & Invasive/Weed & $5 / 6$ & $0.74(0.07) \mathrm{a}$ & $113.60(30.72)$ a & 85.18 (7.51) ab \\
\hline Sonchus hydrophilus & Native & $6 / 6$ & $0.75(0.07) \mathrm{a}$ & $188.67(76.35) \mathrm{a}$ & $66.01(7.56) b$ \\
\hline Actites megalocarpus & Native & $6 / 6$ & $0.88(0.03) \mathrm{a}$ & 214.17 (39.14) a & 82.92 (1.49) ab \\
\hline Reichardia tingitana & Invasive/Weed & $6 / 6$ & $0.55(0.13) \mathrm{a}$ & $66.00(32.68) \mathrm{a}$ & $1.27(0.85) c$ \\
\hline \multicolumn{6}{|l|}{ Lactucinae } \\
\hline Lactuca sativa & Crop & $0 / 6$ & - & - & - \\
\hline Lactuca serriola & Invasive/Weed & $0 / 6$ & - & - & - \\
\hline \multicolumn{6}{|l|}{ Hypochaeridinae } \\
\hline Helminthotheca echioides & Invasive/Weed & $0 / 6$ & - & - & - \\
\hline \multicolumn{6}{|l|}{ Cichoriinae } \\
\hline Cichorium endivia & Crop & $0 / 6$ & - & - & - \\
\hline Cichorium intybus & Crop & $0 / 6$ & - & - & - \\
\hline
\end{tabular}

Note: The sub-tribes have been placed within the table to reflect their phylogenetic relatedness.

Differences among the host plants were compared using ANOVA followed by Tukey's multiple comparison test. Means followed by different letters within columns indicate a significant difference $(p<.05)$.

${ }^{a}$ Number of infested leaves/number of leaves exposed to the midges at the beginning of the test. 
FIGURE 1 Galls of Cystiphora sonchi on different host plants. (a) Sonchus oleraceus; (b) Sonchus hydrophilus; (c) Reichardia tingitana; (d) Actites megalocarpus and (e) Sonchus asper

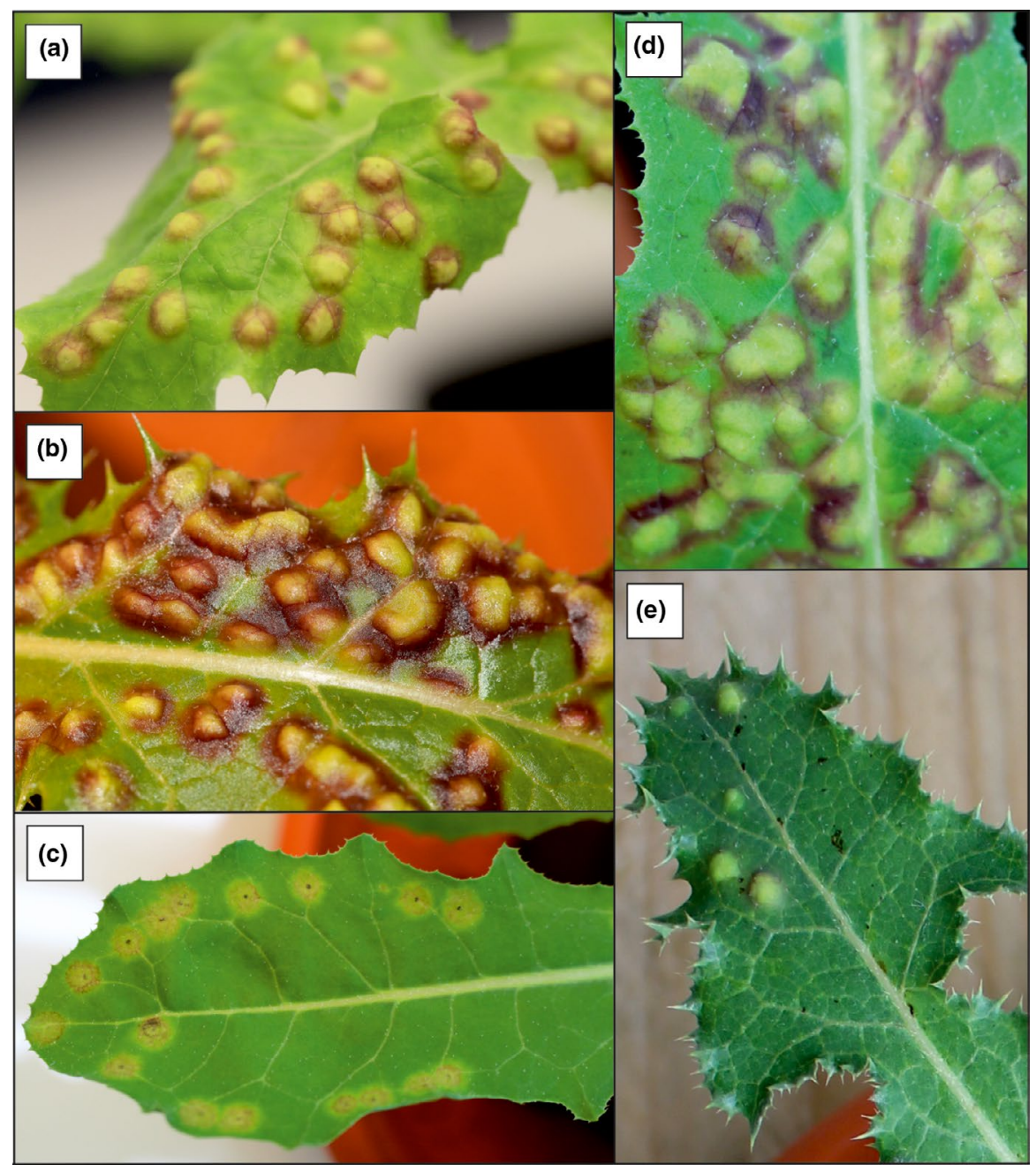

in screened cages $(80 \times 50 \times 80 \mathrm{~cm})$ with a 16-hr: 8 -hr light/dark cycle at $23^{\circ} \mathrm{C} / 19^{\circ} \mathrm{C}$ (day/night). Relative humidity ranged from $30 \%$ to $60 \%$.

\section{3 | Plant material}

All plants used were grown from seeds in standard horticultural grade compost (Neuhaus Humin Substrat N6; Klasmann-Deilmann $\mathrm{GmbH}$ ) in free-draining pots ( $9 \times 9 \mathrm{~cm}$ wide and $10 \mathrm{~cm}$ deep). Plants were tested at the rosette stage, and they were grown in a greenhouse for 6 weeks prior to the tests.

\section{4 | No-choice tests}

Soon before the emergence of adults, infested leaves from the rearing cages were cut and placed on moistened filter paper in plastic containers $(33 \times 22 \times 3 \mathrm{~cm})$. This method allowed newly emerged adults to copulate. Ten females were used for each tested plant. Preliminary observations indicated that most of the females had already mated. Consequently, females used within the tests were collected after $11 \mathrm{hr}$ a.m. However, to ensure to use mated females, four or five males were also added.

The test plants were placed into separate screened cages $(30 \times 30 \times 30 \mathrm{~cm})$. The tests were performed in the same conditions as previously described for insect rearing. Six replicates for each species were used. The 66 cages (i.e. 11 test plants $\times$ six replicates) composing the test were arranged in a completely randomized design.

\section{5 | Choice tests}

To estimate whether $C$. sonchi prefers the target weeds (S. oleraceus and S. asper) over the Australian native plants, choice tests were conducted using a similar method as in no-choice tests. Two series of tests were carried out: the first one considered S. oleraceus, $S$. asper and S. hydrophilus and the second one S. oleraceus, S. asper and A. megalocarpus. These species were selected because they were equivalent hosts under no-choice conditions. However, Reichardia tingitana (L.) Roth was not used in these tests; this species appeared to be sub-optimal for the development of $C$. sonchi. Only the French origin of S. oleraceus was considered in this test. Each series was composed of ten replicates. One potted plant of each of the three 
species was placed in a screened cage $(60 \times 30 \times 30 \mathrm{~cm})$. The same conditions as those described for insect rearing were used for the tests. Ten females and four or five males were introduced into each cage (see above, no-choice tests).

\section{6 | Specificity assessment and damage measurements}

For both tests, the number of leaves exposed to $C$. sonchi was counted for each plant. The test plants were observed for a minimum of two weeks for possible gall development. After this time, infested leaves were cut and placed in a Petri dish on moistened filter paper for adult emergence. The number of infested plants, the number of infested leaves and the number of galls per plant were counted. The number of adults emerged from the infested leaves was counted 15 days after the end of the experiments when no new emergence was observed. The proportion of galls that resulted in an adult was calculated (adult emergence \%).

\subsection{Statistical analyses}

The proportion of infested leaves (number of infested leaves/number of leaves exposed to the midges at the beginning of the test) was calculated for both the no-choice and the choice tests.

All variables were checked for their homoscedasticity (Levene test) and normal distribution (Shapiro-Wilk test). Analysis of variance (ANOVA) was used to analyse the data, and Tukey's HSD test at the $95 \%$ confidence level was applied for separation of means. Data not fitting a normal distribution after transformation were analysed using Kruskal-Wallis test followed by multiple comparisons using Mann-Whitney test with Bonferroni-Holm correction. Statistical analyses were performed with R version 3.5.1 (R Core Team, 2018).

\section{3 | RESULTS AND DISCUSSION}

According to our results, the host range of $C$. sonchi appears to be restricted to the Sonchinae sub-tribe (Table 1). Galls developed only on Sonchus spp., A. megalocarpus and R. tingitana (Figure 1), and none of the species in the other tested sub-tribes showed signs of infestation. Within the Sonchinae, $R$. tingitana was a sub-optimal host for the midge with the production of abnormal galls (Figure 1) and a significantly reduced adult emergence rate (Table 1).

The risk of non-target attack occurring on native plants is generally linked to how closely the native plants are related to the target weed (Hinz, Winston, \& Schwarzländer, 2019). Originally described as Sonchus asper var. megalocarpa Hook. F, A. megalocarpus, endemic to Australia, is a close relative to the genus Sonchus (Kim, Chunghee, \& Mejías, 2007;Kim et al., 2004). This phylogenetic affinity between Actites and Sonchus explains the acceptability of this species to $C$. sonchi. Similarly, the other Australian indigenous species tested, $S$. hydrophilus, is also accepted as a host by $C$. sonchi. (Table 1, Figure 2). These results suggest that S. oleraceus, S. asper, S. hydrophilus and A. megalocarpus are equivalent hosts for $C$. sonchi in a no-choice setting. In the choice tests, $C$. sonchi has a preference for native Australian species; the highest infestations have been observed on those species (Figure 2). The number of leaves exposed at the beginning of the test (data shown in Supplementary material) might influence the observed preference, but this may not explain the differences we observed on their own. As observed in the no-choice tests (Table 1), developmental success (i.e. percentage of adult emergence) is highest on S. oleraceus and S. asper (Figure 2) and lower on native Australian species (Figure 2). However, the number of galls was higher and the percentages of emergence were around $60 \%$ and $85 \%$, respectively, for S. hydrophilus and A. megalocarpus; therefore, the subsequent progeny production stays very high.

Collectively, our results indicated that native Australian plants tested are highly acceptable to $C$. sonchi in no-choice tests and are even preferred compared with the target weeds under choice conditions. Consequently, it is highly likely that the midge has a great potential to persist on these plants if released as a biological control agent. Sonchus species are of major concern in Australian cropping systems but are cosmopolitan weeds, widespread in Australia (McCarren \& Scott, 2013). It may grow in diverse environments including the natural habitats of the native Australian Sonchinae (http://www.ala.org.au), making the colonization of wild S. hydrophilus and A. megalocarpus populations possible. We have therefore rejected $C$. sonchi as a prospective agent for $S$. oleraceus in Australia.

This study also highlights how a biological control agent approved for release in one biogeographic context may need careful screening before release in a different context, based on the phylogenetic affinities between the weed and the flora of the country where CBC is desired. For C. sonchi, only Sonchus spp. were reported as host plants in the literature (Peschken, 1982;Rizzo \& Massa, 1998) and our field surveys confirmed these observations and justified our initial prioritization of the midge as a candidate agent for Australia. In Canada, $C$. sonchi has been released for the biological control of $S$. arvensis (Peschken et al., 1989) but, in contrast to Australia, no native Sonchinae are present (Bremer, 1994).

One of the challenges in a $\mathrm{CBC}$ programme is the logistic constraint of space and environmental conditions in quarantine in which to undertake the host specificity tests. Doing the tests in the native range with an abridged test list, such as the one we used, ensures that only the agents that have passed this first filter are subjected to further testing in a high value and limited space setting of a quarantine laboratory. Our study highlighted the value of testing a few key phylogenetically related species in the first instance. We propose this, in addition to the usual assessments of field host specificity that occurs in the native range for any candidate agent. Our approach to screening the host range of a candidate biological control agent in the native range with an abridged test plant list will be useful for efficient prioritization of 

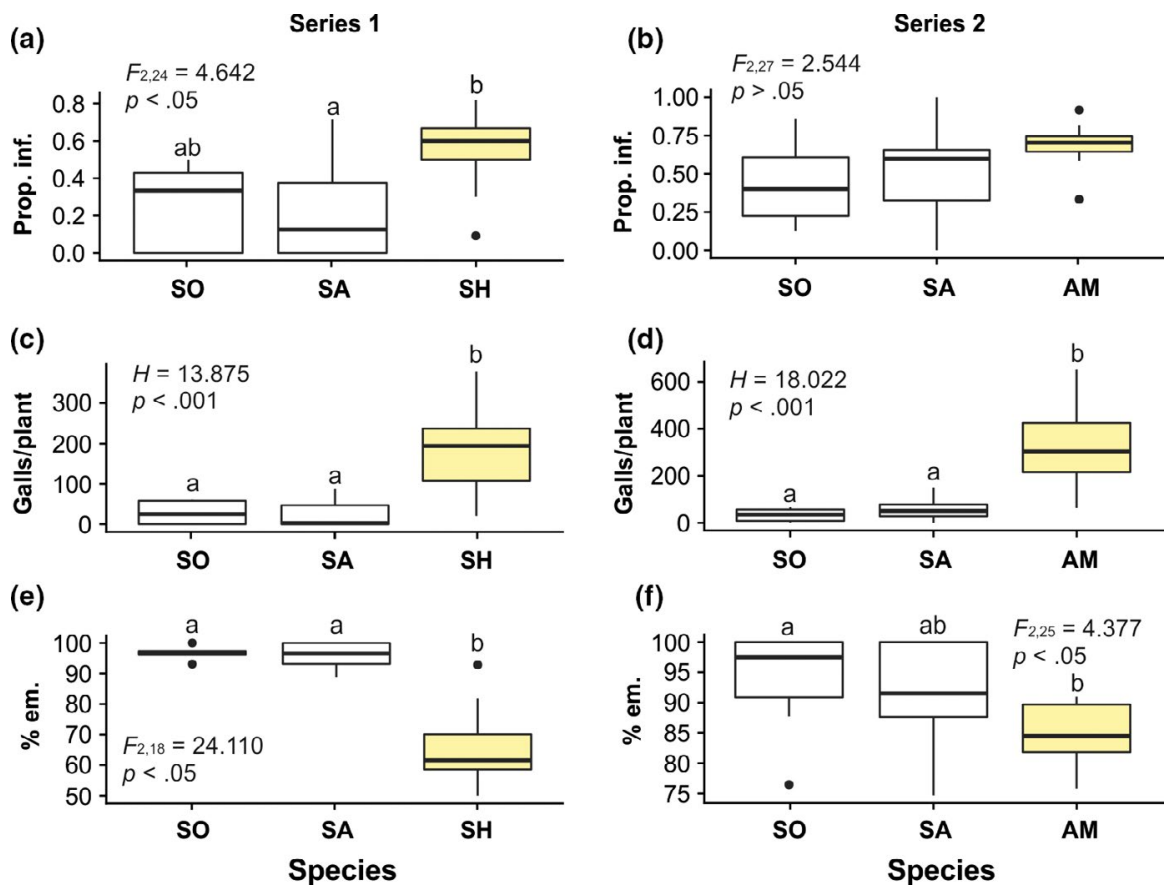

FIGURE 2 Results of choice host range tests for Cystiphora sonchi as measured by: (a, b) the proportion of infested leaves (number of infested leaves/number of leaves exposed to the midges at the beginning of test); (c, d) the number of galls per plant and (e, $f$ ) the percentage of adults emerged. SA = Sonchus asper; SH = Sonchus hydrophilus; SO = Sonchus oleraceus; AM = Actites megalocarpus. The boxes of the native Australian species are coloured in yellow. The boxes represent the first to third quartile range with the median indicated by a line across the box. Differences among the host plants for the proportion of infested leaves and the percentage of adults emerged were compared using ANOVA followed by Tukey's multiple comparison test. The differences between the number of galls per plant were evaluated by KruskalWallis tests followed by multiple comparisons using Mann-Whitney tests. The samples flanked by different letters differ significantly at $p=.05$.

further candidate agents for S. oleraceus, and possibly for candidate agents of other weeds.

\section{ACKNOWLEDGMENTS}

This project was supported by funding from the Australian Government Department of Agriculture, as part of its Rural R\&D for Profit programme, through AgriFutures Australia (Rural Industries Research and Development Corporation) (PRJ--010527). We thank Rieks van Klinken and two anonymous reviewers for their feedback on an earlier version of this manuscript.

\section{CONFLICT OF INTEREST}

No potential conflict of interest was reported by the authors.

\section{AUTHOR CONTRIBUTION}

VL and TT conceived research; VL and TT conducted experiments; $\mathrm{MO}$ contributed material; VL analysed data and conducted statistical analyses; VL and SR wrote the manuscript; SR secured funding. All authors read and approved the manuscript.

\section{DATA AVAILABILITY STATEMENT}

The data that support the findings of this study can be found in the Supporting information file (Data S1).

\section{ORCID}

Vincent Lesieur (iD https://orcid.org/0000-0003-3374-6004

Sathyamurthy Raghu iD https://orcid.org/0000-0001-5843-5435

\section{REFERENCES}

Barratt, B., Moran, V., Bigler, F., \& van Lenteren, J. (2017). The status of biological control and recommendations for improving uptake for the future. BioControl, 1-13.

Boulos, L. (1973). Révision systématique du genre Sonchus I. S.L. Iv. Sousgenre I. Sonchus. Botaniska Notiser, 126, 155-196.

Bremer, K. (1994). Cladistics and claasification. Portland: Timber Press.

Briese, D. (2005). Translating host-specificity test results into the real world: The need to harmonize the yin and yang of current testing procedures. Biological Control, 35, 208-214.

DeClerck, R. A., \& Steeves, T. A. (1988). Oviposition of the gall midge Cystiphora sonchi (Bremi) (Diptera: Cecidomyiidae) via the stomata of perennial sowthistle (Sonchus arvensis I.). The Canadian Entomologist, 120, 189-193.

Heard, T. A., \& Klinken, R. D. V. (2004). Rapid preliminary characterisation of host specificity of leaf-beetles (Coleoptera: Chrysomelidae). Biocontrol Science and Technology, 14, 499-511.

Hinz, H. L., Winston, R. L., \& Schwarzländer, M. (2019). How safe is weed biological control? A global review of direct nontarget attack. The Quarterly Review of Biology, 94, 1-27.

Hunter, C. G., \& Morin, L. (2018). Proposed plant host test list for assessing risk of candidate biological control agents for Sonchus oleraceus. Canberra, Australia: CSIRO. 
Kim, S.-C., Chunghee, L., \& Mejías, J. A. (2007). Phylogenetic analysis of chloroplast DNA matk gene and its of nrdna sequences reveals polyphyly of the genus Sonchus and new relationships among the subtribe Sonchinae (Asteraceae: Cichorieae). Molecular Phylogenetics and Evolution, 44, 578-597.

Kim, S.-C., Lu, C. T., \& Lepschi, B. J. (2004). Phylogenetic positions of Actites megalocarpa and Sonchus hydrophilus (Sonchinae: Asteraceae) based on its and chloroplast non-coding DNA sequences. Australian Systematic Botany, 17, 73-81.

Manalil, S., Werth, J., Jackson, R., Chauhan, B. S., \& Preston, C. (2017). An assessment of weed flora 14 years after the introduction of glyphosate-tolerant cotton in Australia. Crop and Pasture Science, 68, 773-780.

McCarren, K. L., \& Scott, J. K. (2013). Host range and potential distribution of Aceria thalgi (acari: Eriophyidae): A biological control agent for sonchus species. Austral Entomology, 52, 393-402.

Osten, V. A., Walker, S. R., Storrie, A., Widderick, M., Moylan, P., Robinson, G. R., \& Galea, K. (2007). Survey of weed flora and management relative to cropping practices in the north-eastern grain region of australia. Australian Journal of Experimental Agriculture, 47, 57-70.

Peerzada, A. M., O'Donnell, C., \& Adkins, S. (2019). Biology, impact, and management of common sowthistle (Sonchus oleraceus L.). Acta Physiologiae Plantarum, 41, 136.

Peschken, D. (1982). Host specificity and biology of Cystiphora sonchi [Dip.: Cecidomyiidae], a candidate for the biological control of Sonchus species. Entomophaga, 27, 405-415.

Peschken, D., McClay, A., Derby, J., \& DeClerck, R. (1989). Cystiphora sonchi (Bremi) (Diptera: Cecidomyiidae), a new biological control agent established on the weed perennial sow-thistle (Sonchus arvensis L.) (Compositae) in Canada. The Canadian Entomologist, 121, 781-791.

R Core Team. (2018). R: A language and environment for statistical computing. Vienna, Austria: R Foundation for Statistical Computing.

Rizzo, M. C., \& Massa, B. (1998). On two italian gall midges (Diptera Cecidomyiidae) and their parasitoids. Entomologica, 32, 121-131.

Scott, J. K., \& McCarren, K. (2012). Sonchus oleraceus L. - sowthistle. In M. Julien, R. McFadyen, \& J. Cullen (Eds.), Biological control of weeds in Australia (pp. 563-568). Melbourne, Australia: CSIRO Publishing.

Wapshere, A. (1974). A strategy for evaluating the safety of organisms for biological weed control. Annals of Applied Biology, 77, 201-211.

\section{SUPPORTING INFORMATION}

Additional supporting information may be found online in the Supporting Information section.

How to cite this article: Lesieur V, Thomann T, Ollivier M, Raghu S. Making host specificity testing more efficient: Exploring the use of abridged test plant lists. J Appl Entomol. 2020;00:1-6. https://doi.org/10.1111/jen.12760 